\title{
Antibiogram Profiles of Bacterial Isolates from Intensive Care Units in Mosul Teaching Hospitals
}

\author{
Zainab A. Al-Jawady \\ Haitham M. Al-Habib \\ Department of Microbiology \\ College of Medicine \\ University of Mosul
}

(Received 4/ 10/2011 ; Accepted 31/10/2011)

\begin{abstract}
The study was conducted to identify the types and frequencies of bacterial isolates from patients with Intensive Care Units-acquired infections, and to determine their antibiogram profile. One hundred and fifty four clinical samples were collected from 101 patients who developed clinical suggestion of new infections of urinary tract, lower respiratory tract or wound following the 48 hours of their admission to the Intensive Care Units. All samples were cultured on different culture media, and the isolated microorganisms were identified by the conventional bacteriological methods. The antibiogram profile of selected antibacterial agents was tested. The total number of the bacterial isolates was 69 miroorganisms. Gram-negative bacteria were more frequently encountered (82.6\%) than the Gram-positive ones(17.4\%) among all samples. The predominant Gram-negative isolate was E. coli $(23.2 \%)$, followed by Pseudomonas spp. (21.7\%), K. pneumoniae (14.5\%), Proteus spp. (11.6\%)., Acinetobacter spp. (8.7\%), and E.aerogenes (2.9\%). The predominant Gram-positive bacterial isolate was S.aureus (7.2\%), followed by E. faecalis (5.8\%), and S.epidermidis (4.3\%). The most effective antimicrobial agents were amikacin, ciprofloxacin, vancomycin, gentamicin, chloramphenicol, and azithromycin.
\end{abstract}

Keywords: ICUs, Bacterial isolates, Antibiogram profile.

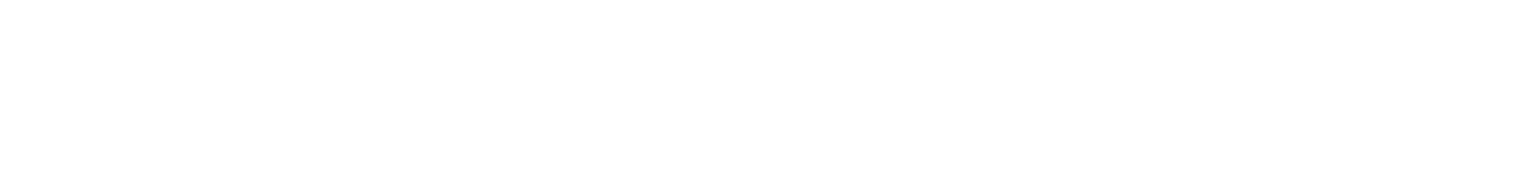

\section{الملغص}

لجريت هذه الدرلسة لتحديد أنواع و تكرار الجراثيم المعزولة من المرضى الذن يعانون من أخماج

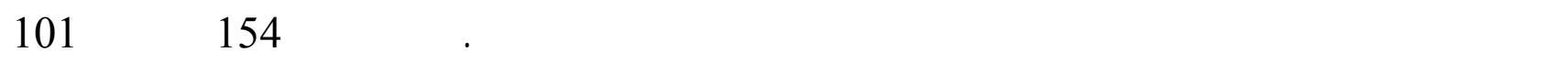

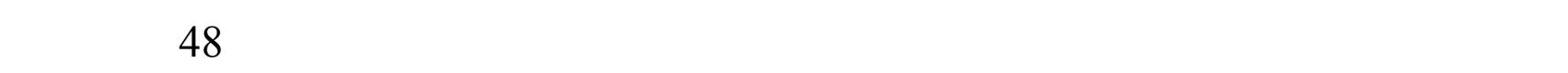

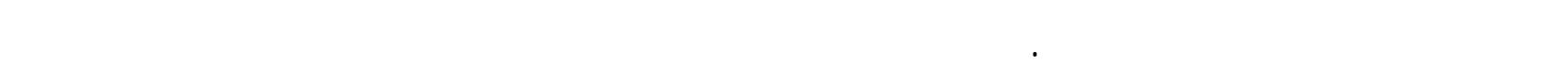
الفحوصات البكتريولوجية القليية. وقد فم لختبار هسلسية الجراثيم المعزولة لعدد من أنواع المضادات 
الحيوية. أظهرت النتائج إن العدد الكلي للجراثيم المعزولة هو 69 جرثومة. و قد كالت الجراثيم اللسالبة لصبغة كرله (82.6\%) الأكثر تكرارا من الجراثيم الموجبة لصبغة كرله (17.4\%) من بين جمبع العينت.

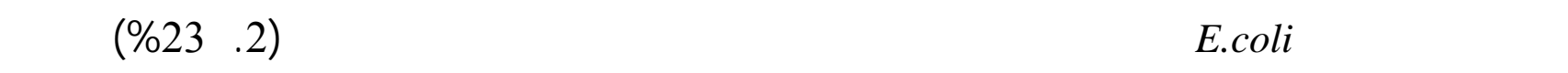
Acinetobacter ، (\%11.6)Proteus spp. ،\%14.5) K. pneumoniae ، (7) (7) Pseudomonas spp. spp.

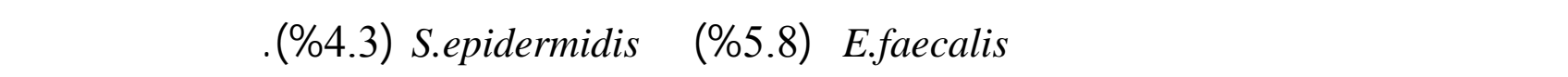

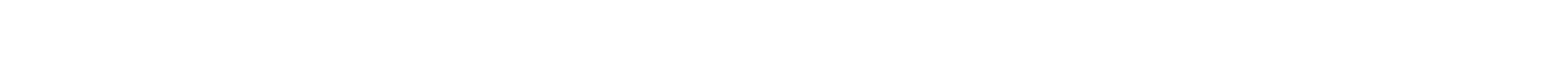
وكلورلمفينيكول وازيثرومليسين.

الكاملت الدالة: وحدات العناية المركزة، العزلات الجرثومية، نهط التهس للمضادات الحيوية. INTRODUCTION

Nosocomial infection (NI) is defined as an infection acquired by a patient in a hospital or other healthcare facility that was not present or incubating at the time of admission, or that was the residual of an infection acquired during a previous admission (WHO, 2002). The time frame for diagnosis of a NI will clearly be dependent on the incubation period of the specific infection, thus, 48 hours after admission is generally deemed indicative of nosocomial rather than community acquired infection (Garner et al.,1988).

Although $5 \%$ to $10 \%$ of all patients are treated in intensive care units (ICUs), they constitute about $25 \%$ of all NIs and the incidence is 5 to 10 times higher than in general hospital wards (Al - Johani et al., 2010), which means that NIs are specially prominent in ICU (Ewans et al., 1999). This may be related to the use of large numbers of invasive monitoring devices, endotracheal and tracheostomy tubes, in addition to patients factors including extremes of age, immunocompromised status, malnutrition, severe underlying disease, wide use of antibiotics and to a high incidence of cross infection (Weber et al., 1999).

The three most common NIs are ventilator-associated pneumonias, urinary tract infections, and blood stream infections (Richards et al., 1999).

There is a wide diversity between institutions in the prevalence of pathogens and in their antimicrobial susceptibility (Fridkin, 2001). Therefore, this study aims to determine the types and frequencies of bacterial isolates from patients with ICUs-acquired infections, as well as the susceptibility patterns of these bacterial isolates to selected antibiotics which is essential to produce empirical antibiotic protocols for individual ICU.

\section{PATIENTS AND METHODS}

This study was approved by the scientific research committee at the College of Medicine, University of Mosul. Formal consent was taken from all patients after careful examination. 
The present work was carried out in the Diagnostic Bacteriology Laboratory, Department of Microbiology, College of Medicine, University of Mosul during the period from December 2010 to June 2011.

The subjects enrolled in the current study were composed of one hundred and one patients admitted into three ICUs, including Cardiac Care Unit (CCU), Critical and Respiratory Care unit (RCU) in Ibn Sinna Teaching Hospital and Surgical Care Unit (SCU) in Aljamhori Teaching Hospital. These patients developed clinical suggestion of new infections of urinary tract, lower respiratory tract or wound following the 48 hours of their admission to the ICUs.

Samples, if present, were collected from patients at the time of their admission to ICUs or during the first 48 hours of their admission if there was clinical suggestion of an infection. Any positive finding during this period was considered as a pre-existing infection and the results were not included in this study. This was done just to differentiate the new infection from the pre-existing one. In addition, any patient died or was discharged before passing 48 hours on his admission to the ICU was excluded from the study. In case of readmisson of patient to the ICU, he was considered as a new case.

A total of 154 clinical samples were collected from the studied patients following the 48 hours of their admission in the above mentioned three ICUs. The specimens consisted of $83(53.9 \%)$ urine samples, $44(28.6 \%)$ respiratory samples, and $27(17.5 \%)$ wound samples. After collection of the clinical samples, they were transferred to the laboratory without undue delay for processing, and inoculation. Different culture media were used for inoculation including sheep blood agar (5\%), Chocolate agar, MacConkey's agar, and Nutrient agar (Oxoid, UK). All media were incubated at $37^{\circ} \mathrm{C}$ for 24 hours, with further 24 hours incubation if there was no growth.

The microorganisms were identified by the conventional bacteriological methods depending on Gram's stain, cultural characteristics, and standard biochemical tests. Furthermore, the susceptibility of the bacterial isolates were determined against selected antibacterial agents using discs diffusion method (Bauer et al., 1966) on Mueller-Hinton agar (Oxoid, UK).

\section{STATISTICAL ANALYSIS}

Statistical analysis was performed by using Mini Tab version 13. Chi-square was used to evaluate the present data. Statistically test results were considered significant at $p$-value $\leq$ 0.05 (Kirkwood, 1988).

\section{RESULTS}

The studied patients composed of 52(51.5\%) females and 49(48.5\%) males.

The age of the patients ranged from 5-85 years (mean 52.5 $\pm 16.8 \mathrm{SD}$ ), whereas, the duration of stay of these patients in the ICUs ranged from 3-32 days (mean 7.1 $\pm 4.6 \mathrm{SD}$ ).

The samples were collected from $35(34.7 \%)$ patients of CCU, 33(32.7\%) patients of RCU, and 33(32.7\%) patients of SCU.

Out of the total 101 studied patients, 53(52.5\%) had ICUs acquired bacterial infections. From these 53 infected patients, 39(73.6\%) individuals developed only one infection, while the rest $14(26.4 \%)$ developed more than one type of infection. The remaining 48(47.5\%) patients showed negative bacterial growth. Yeasts were isolated from $21(20.8 \%)$ of them. The rest $27(26.7 \%)$ patients did not show any defined growth (Fig. 1). 


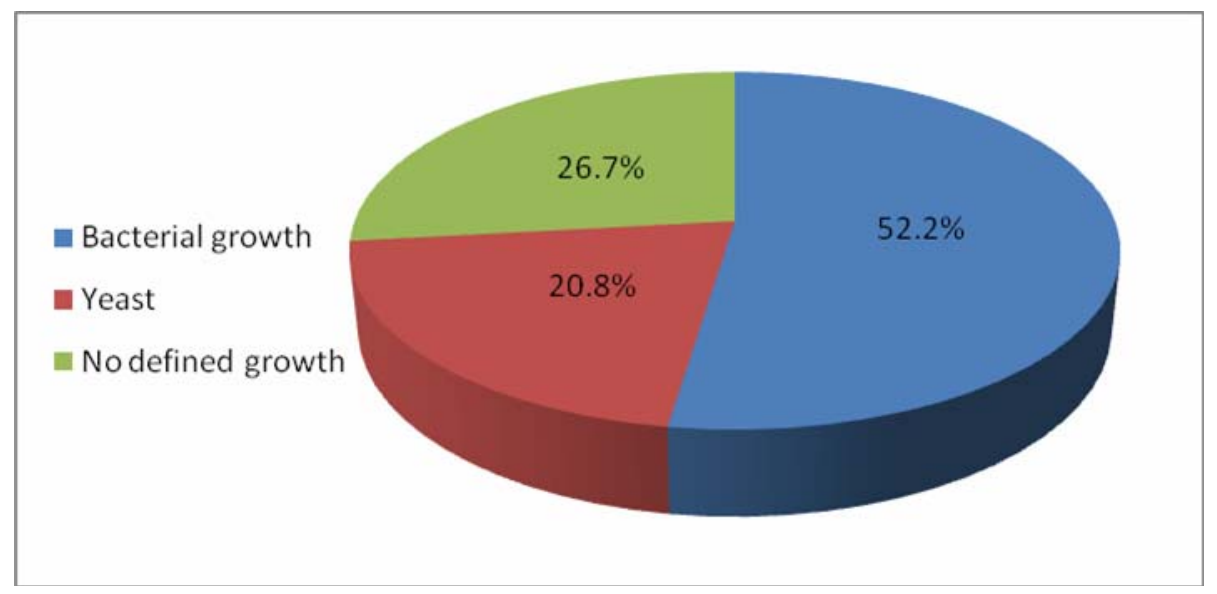

Fig. 1: The comprehensive results of culture technique

Out of the 67 samples which yielded positive cultures, 65(97\%) showed monomicrobial infections, while polymicrobial infections were detected in $2(3 \%)$ samples only.

The total number of the isolated bacteria was 69 of which Gram-negative bacteria were more frequently encountered $(57,82.6 \%)$ than the Gram-positive ones $(12,17.4 \%)$. The predominant isolate for Gram-negative bacteria was E.coli 16(23.2\%), followed by Pseudomonas spp. 15(21.7\%), where P.aeruginosa comprised 10 (66.7\%), K.pneumoniae 10(14.5\%), Proteus spp. 8(11.6\%), where P.mirabilis constituted 6(75\%) and P.vulgaris $2(25 \%)$, Acinetobacter spp. 6(8.7\%), E.aerogenes $2(2.9 \%)$. On the other hand, the predominant Gram-positive bacterial isolate was S.aureus $5(7.2 \%)$, followed by E.faecalis 4(5.8\%), and S.epidermidis 3(4.3\%) as shown in Table 1.

Table 1: The total number of bacteria isolated from the three types of infection.

\begin{tabular}{|c|c|c|c|c|}
\hline \multirow{2}{*}{$\begin{array}{l}\text { Bacterial } \\
\text { isolates }\end{array}$} & \multicolumn{3}{|c|}{ Type of infection } & Total \\
\hline & \begin{tabular}{c}
\multicolumn{2}{c}{ RTIs } \\
No. $(\%)$
\end{tabular} & \begin{tabular}{l}
\multicolumn{2}{c}{ UTIs } \\
No. $(\%)$
\end{tabular} & $\begin{array}{c}\text { Wound infection } \\
\text { No. (\%) }\end{array}$ & No. (\%) \\
\hline \multicolumn{5}{|c|}{ Gram-negative } \\
\hline E.coli & - & $9(28.1)$ & $7 \quad(46.7)$ & $16 \quad(23.2)$ \\
\hline Pseudomonas Spp. & $8(36.4)$ & $4(12.5)$ & $3 \quad(20)$ & $15 \quad(21.7)$ \\
\hline K.pneumoniae & $6 \quad(27.3)$ & $4(12.5)$ & & $10 \quad(14.5)$ \\
\hline Proteus spp. & $1 \quad(4.5)$ & $5(15.6)$ & $2(13.3)$ & $8 \quad(11.6)$ \\
\hline Acinetobacter spp. & $4(18.2)$ & $2(6.3)$ & & $6 \quad(8.7)$ \\
\hline E.aerogenes & - & $2 \quad(6.3)$ & - & $2(2.9)$ \\
\hline Subtotal & $19(86.4)$ & $26(81.3)$ & $12 \quad(80)$ & $57(82.6)$ \\
\hline \multicolumn{5}{|c|}{ Gram-positive } \\
\hline S.aureus & $2(9.1)$ & $1 \quad(3.1)$ & $2 \quad(13.3)$ & $5 \quad(7.2)$ \\
\hline E.faecalis & $1 \quad(4.5)$ & $2(6.3)$ & $1 \quad(6.7)$ & $4 \quad(5.8)$ \\
\hline S.epidermidis & & $3 \quad(9.4)$ & $=$ & $3 \quad(4.3)$ \\
\hline Subtotal & $3(13.6)$ & $6(18.8)$ & $3 \quad(20)$ & $12(17.4)$ \\
\hline Total & $22(31.9)$ & $32(46.4)$ & $15(21.7)$ & $69(100)$ \\
\hline
\end{tabular}


Statistically there was significant difference between the isolated number of Gramnegative and Gram-positive bacteria where the $\mathrm{P}$-value was $<0.05$.

The antibiogram profiles of the isolates are shown in figure 2 and 3. Amikacin (74.3\%), followed by ciprofloxacin (71.5\%), chloramphenicol (66\%), and tobramycin $(65.6 \%)$ are the effective agents against Gram-negative bacteria. Conversely, the least effective antibiotic was co-amoxiclav (0\%). In addition, the sensitivity of Pseudomonas spp. to piperacillin and ticarcillin were $40 \%$ and $13.3 \%$ respectively. Moreover, the sensitivity of Acinetobacter spp. to colistin was $100 \%$.

On the other hand, the most effective antibiotics against Gram-positive bacteria were, vancomycin (100\%), amikacin (100\%), gentamicin (100\%), chloramphenicol $(100 \%)$, followed by azithromycin $(73.9 \%)$.

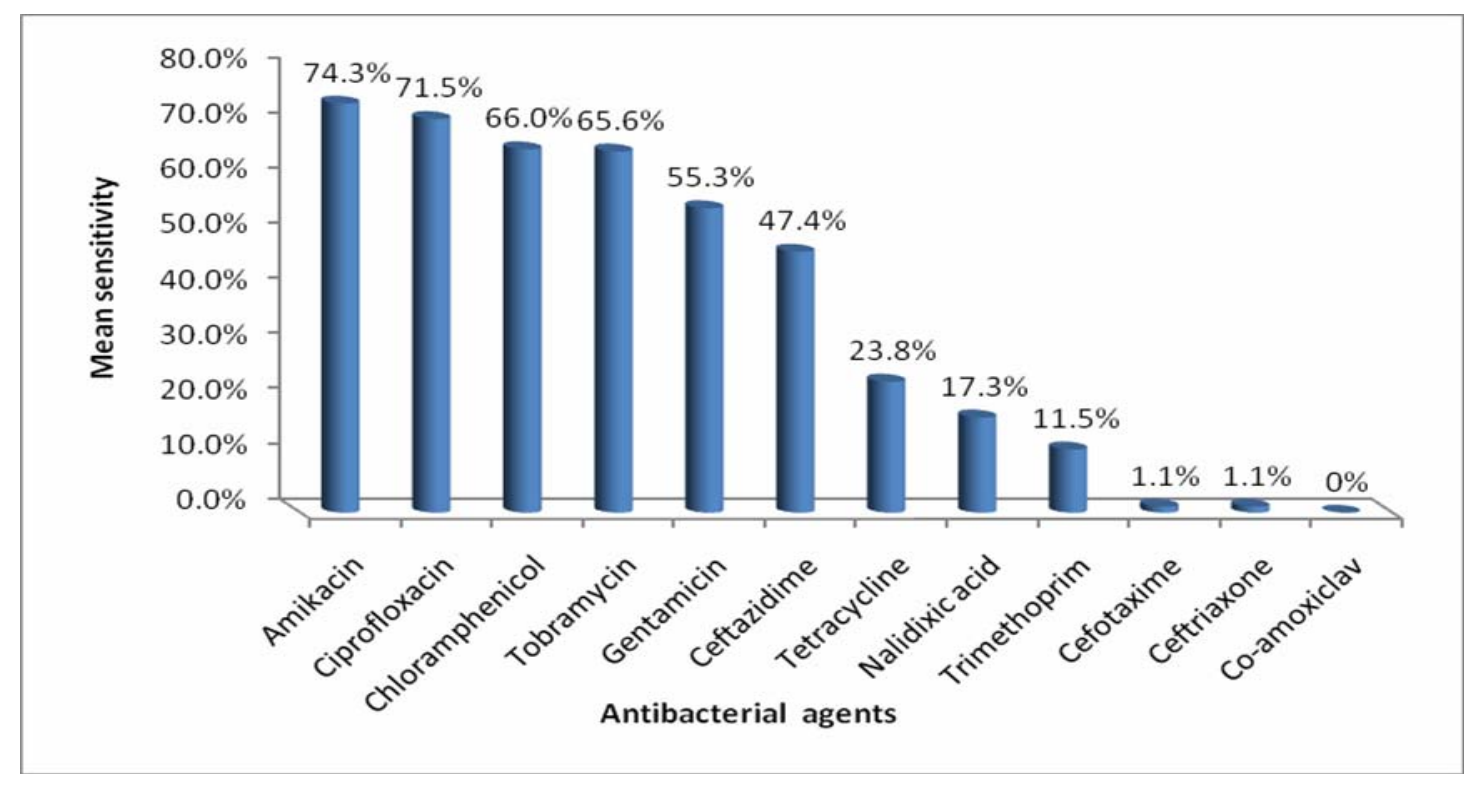

Fig. 2: Mean sensitivity percentages of Gram-negative isolates to twelve antibacterial agents.

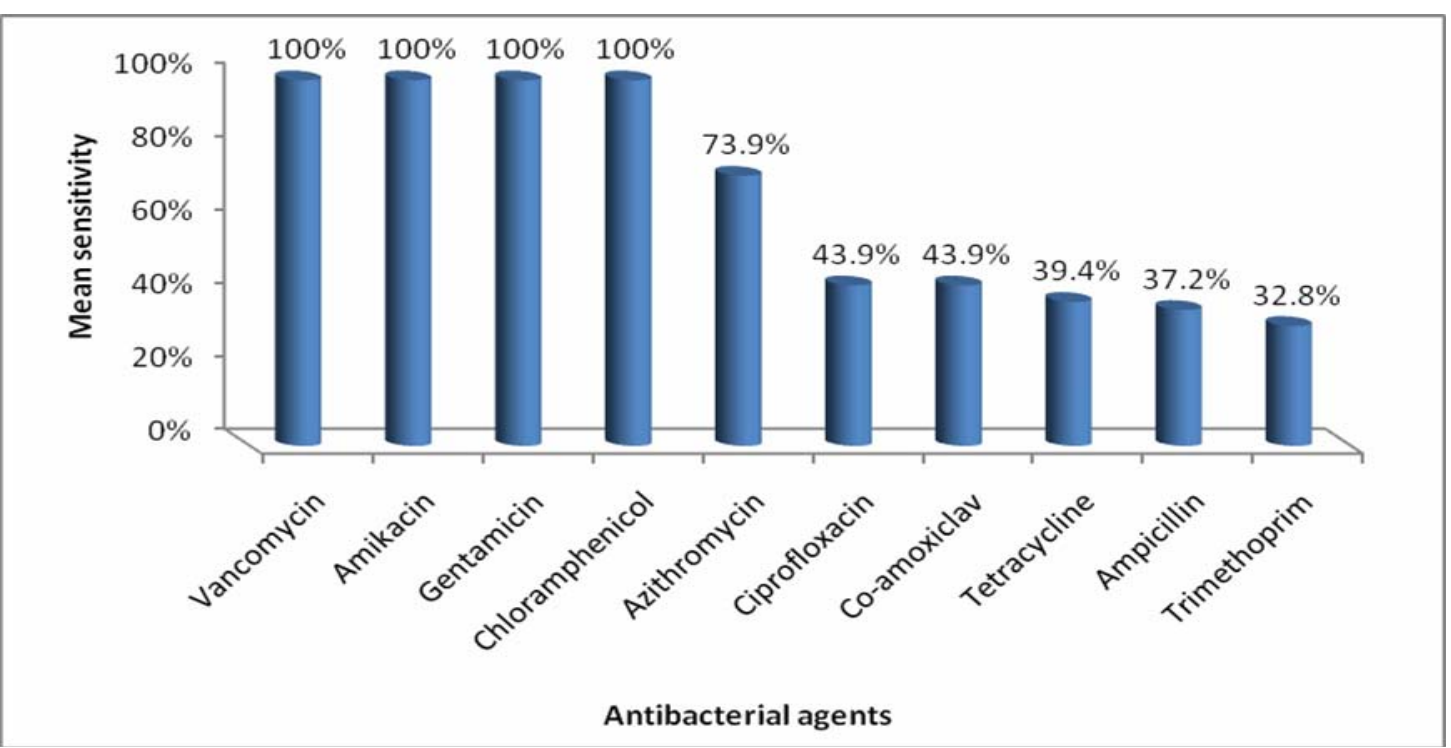

Fig. 3: Mean sensitivity percentages of Gram-positive isolates to ten antibacterial agents. 


\section{DISCUSSION}

NIs in ICUs have become increasingly problematic in the recent years, nevertheless, no records about these infections are available in our area, hence, this study was carried out to assess this problem. In the current study, $52.5 \%$ of the examined patients were supported by positive bacterial cultures. This result was in agreement with that of another study(Hassanzadeh et al., 2009) in which $51.7 \%$ of the total examined patient showed NI based on culture and clinical findings.

The possible explanations for the negative bacterial culture yielded by the remaining $47.5 \%$ of individuals are either those patients had no NIs, or the causative agents could be of atypical microorganisms that cannot grow on the traditionally used bacteriological culture media. Furthermore, urine and sputum cultures of $20.8 \%$ of the examined patients yielded yeast cells (Candida spp.), and this result is similar to that (22\%) mentioned by Tennant et al., (2005). This finding may be due in part to the immunocompromised state of such patients and the use of broad-spectrum antibiotics.

Out of the total $52.5 \%$ nosocomially infected individuals, $73.6 \%$ had only one sort of infection, while the rest $26.4 \%$ developed more than one type of infection. These findings were in contrast to that of another study(Hassanzadeh et al., 2009) in which $80.4 \%$ of the infected patients had more than one type of infection while the remaining $19.6 \%$ developed one infection only. The development of more than one infection in a single individual may reflects the presence of a severe underlying disease, or may be due to other factors that cause immunocompromisation.

In this study, out of the total 69 bacterial isolates, Gram-negative bacteria were more significantly involved in infections $(57,82.6 \%)$ than were Gram-positive bacteria (12, $17.4 \%$ ). This predominance of Gram-negative bacteria was coincident with the finding of some recent studies(Hassanzadeh et al., 2009; Nicoletti et al., 2006), which may be due to their wide prevalence in the hospital environment, and most of them represented a wide range of normal flora. In addition, their frequent resistance to antibiotic may play a role in their persistence and spread.

The Enterobacteriaceae represented the most frequently isolated pathogens in the current work (52\%), E.coli (23.2\%), K.pneumoniae (14.5\%), Proteus spp. (11.6\%), and E.aerogenes (2.9\%). In addition, Pseudomonas spp. (21.7\%) ranked second to E.coli. This finding was in contrast to that of Ponce de Leon-Rosales et al., (2000) in which Enterobacteriaceae represented $25.9 \%$, and Pseudomonas spp. constituted $17.2 \%$. However, the members of Enterobacteriaceae are widely diffused in the human body as normal flora, which make them one of the most important available endogenous bacteria ready for NI in immunocompromised patients. While Pseudomonas spp. are widely distributed in the environment, in the water, and even in some medical instruments and machines as the ventilator circuit.

Other Gram-negative isolates were Acinetobacter spp., in this study they represented $8.7 \%$ of the bacterial isolate, while in other studies they constituted $11.9 \%$ ( Erbay et al., 2003), 14.6\% ( Salomao et al., 2008), and 26.8\% ( Meric et al., 2005). Thus, there are a clear regional differences and variation in the prevalence of Acinetobacter spp.. This may be due to the variation in the local infection control measures which may alter the infection rates.

Concerning the Gram-positive bacteria, the predominant isolate was S.aureus which represented $7.2 \%$ of the total bacterial isolates, followed by E.faecalis (5.8\%), and 
S.epidermidis (4.3\%). In another study ( Erbay et al., 2003) the predominant Gram-positive microorganism was S. aureus $(11.3 \%)$, and CONS (8.4\%). While another investigator reported a percentages of $20 \%$ and $18.7 \%$ for CONS and E. faecalis respectively which were the most frequent isolates of Gram-positive microorganisms (Tennant et al., 2005).

The overall decrease in the percentage of Gram-positive bacteria in comparison to the Gram-negative bacteria may be due to the direction of empirical therapy towards the Grampositive one, in the time that the Gram-negative bacteria show resistance to this therapy.

However, the distribution of pathogenic microorganisms tends to vary among the different ICU studies (Fridkin, 2001 ; Meric et al., 2005).

The isolated Gram-negative bacteria showed high resistance to many of the tested agents, including trimethoprim, ceftriaxone, cefotaxime, and co-amoxiclav. This finding was in accordance with that of other studies(Goel et al., 2009 ; Taher and Golestanpour, 2009) in which there was an alarmingly high rate of resistance to cephalosporin and Betalactam-Beta-lactamase inhibitor group of drugs. This high rate of resistance might be due to the selective influence of extensive usage of these drugs.

On the other hand, the most effective antibiotic against Gram-negative bacteria including Pseudomonas spp. was amikacin, followed by ciprofloxacin, chloramphenicol, tobramycin, gentamicin, and ceftazidime. This result was in agreement with that of other studies(Hassanzadeh et al., 2009; Taher and Golestanpour, 2009)in which amikacin, ciprofloxacin, and ceftazidime were the most active agents against the Gram-negative isolates.

The sensitivity of Acinetobacter to colistin was $100 \%$. This result was consistent with that of other studies (Urban et al., 2003; Linden and Paterson, 2006) in which colistin was the most active agent.

Regarding the Gram-positive bacteria, all isolates of S.aureus, S.epidermidis, and E.faecalis showed a full sensitivity to vancomycin, amikacin, gentamicin, and chloramphenicol. This high level of sensitivity may be due to the less frequent use of such antibiotics in hospitals. Also, azithromycin had a good activity (73.9\% ) against these types of bacteria.

\section{CONCLUSIONS}

The Gram-negative bacteria were the major cause of infections in the ICUs. The commonest isolates were E. coli, Pseudomonas spp., and K. pneumoniae. The best empirical therapy should include amikacin or ciprofloxacin with vancomycin or azithromycin which will provide an adequate coverage while waiting for culture and sensitivity results.

\section{REFERENCES}

Al Johani, S. M.; Akhter, J.; Balkhy, H.; El-Saed, A.; Younan, M.; Memish, Z. (2010). Prevalence of antimicrobial resistance among Gram-negative isolates in an adult ICU at a tertiary care center in Saudi Arabia. Ann. Saudi Med., 30(5), 364-369.

Bauer, A.W.; Kirby, W.A.; Sherris, J.S.; Turck, M. (1966). Antibiotic susceptibility testing by standardized single disc method. AM. J. Clin. Pathol., 45(4),493-496.

Erbay, H.; Yalcin, A.N.; Serin, S.; Turgut, H.; Tomatir, E.; Cetin, B.; Zencir, M. (2003). NIs in ICU in a Turkish university hospital: a 2-year survey. Intensive Care Med., 29(9), 1482-1488. 
Ewans, T.M.; Ortiz, C.R.; LaForce, F.M. (1999). " Intensive Care Medicine" 4th ed., Irwin, R.S.; Cerra, F.B.; and Rippe, J.M., Lippincot-Raven, New York, pp. 1074-1080.

Fridkin, S.K. (2001). Increasing prevalence of antimicrobial resistance in ICUs. Crit. Care Med., 29(4),64-68.

Goel, N.; Chaudhary, U.; Aggarwal, R.; Bala, K. (2009). Antibiotic sensitivity pattern of Gram- negative bacilli isolated from the lower respiratory tract of ventilated patients in the ICU. Ind. J. Crit. Care Med., 13(3), 148-151.

Garner, J.S.; Jarvis, W.R.; Emori, T.G.; Horan, T.C.; Hughes, J.M. (1988). Center of Disease control and prevention definitions for NIs. Am. J. Infect. Control. ,16(3), 128-140.

Hassanzadeh, P.; Motamedifar, M.; Hadi, N. (2009). Prevalent bacterial infections in ICUs of Shiraz University of Medical Sciences Teaching Hospitals, Shiraz, Iran. Jpn. J. Infect. Dis., 62(4), 249-253.

Kirkwood, B.R. (1988)." Essentials of Medical Statistic". Black well scientific publications. pp 46-56.

Linden, P.K.; Paterson, D.L. (2006). Parenteral and inhaled colistin for treatment of ventilator associated pneumonia. Clin. Infect. Dis., 43(2), 89-94.

Meric, M.; Willke, A.; Caglayan, C.; Toker, K. (2005). ICU acquired infection: Incidence, Risk factors and Associated Mortality in Turkish University Hospital. Jpn. J. Infec. Dis., 58(5), 297-302.

Nicoletti, G.; Schito, G.; Fadda, G.; Boros, S.; Nicolosi, D.; Marchese, A.; Spanu, T.; Pantosti, A.; Monaco, M.; Rezza, G.; Cassone, A.; Garaci, E. (2006). Bacterial isolates from severe infections and their antibiotic susceptibility patterns in Italy: a nationwide study in the hospital setting. J. Chemother., 18(6), 589-602.

Ponce de Leon-Rosales, S.P.; Molinar-Ramos, F.; Dominquez-Cherit, G.; Rangel-Frausto, M.S.; Vazquez-Ramos, V.G. (2000). Prevalence of infections in ICUs in Mexico: A multicenter study. Crit. Care Med. ,28(5), 1316- 1321.

Richards, M.J.; Edwards, J.R.; Culver, D.H.; Gaynes, R.P. (1999). NIs in medical ICUs in the United States. NNIS System. Crit.Care Med., 27(5), 887-892.

Salomao, R.; Rosenthal, V.D.; Grimberg, G.; Nouer, S.; Blecher, S.; Buchner-Ferreira, S.; Vianna, R.; Maretti-da-Silva, M.A. (2008). Device-associated infection rates in ICUs of Brazilian hospitals: findings of the International Nosocomial Infection Control Consortium. Rev Panam Salud Publica. Pan. Am. J. Public Health., 24(3), 195-202.

Taher, M.T.; Golestanpour, A. (2009). Symptomatic nosocomial UTI in ICU patients: identification of antimicrobial resistance pattern. Iran. J. Clin. Infect. Dis., 4(1), 2529.

Tennant, I.; Harding, H.; Nelson, M.; Roye-Green, K. (2005). Microbial isolates from patients in an ICU, and associated risk factors. West Ind. Med. J., 54(4), 225-231.

Urban, C.; Segal-Maurer, S.; Rahal, J.J. (2003). Considerations in control and treatment of NIs due to multidrugresistant A. baumannii. Clin. Infect. Dis., 36(10), 1268-1274.

Weber, D. J.; Raasch, R. ; Rutala, W.A. (1999). NIs in the ICU. The growing importance of antibiotic-resistant pathogens. Chest., 115(1),34-41.

World Health Organization, (2002). Guidelines on prevention and control of hospital associated infection. New Delhi, WHO Regional Office for South-East Asia. 